\section{Aspects of the} impact of interest rate development on the

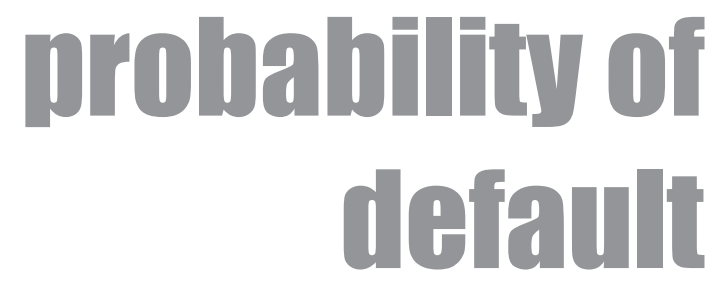

Luminița Gabriela ISTRATE, Academy of Economic Studies from Bucharest,

Email: istrate_luminita@yahoo.com

Bogdan Ştefan IONESCU, Academy of Economic Studies from Bucharest, Email: ionescub@gmail.com

Maria-Monica HARALAMBIE, Academy of Economic Studies from Bucharest,

Email: haralambie.monica@gmail.com

\section{Aistract}

The acceptance of banking risks and their control is one of the key moments in banking activity. Success in banking management is possible only if the risks accepted by banks are reasonable, can be controlled and do not exceed the financial resources and their expertise.

The occurrence of the interest rate risk is due to the holding a portfolio of assets and liabilities with fixed interest, different in terms of maturities and price and in terms of ownership of assets and liabilities with variable interest that adapts differently to interest rate fluctuations.

The estimation of the probability of default is the first step to determine and assess risk. The major issues in the estimation of $P D$ are generated by the limitation of the required information.

This work captures the impact of interest rate on the $P D$ at maturity of loans. The analysis covers the period January 2013 - December 2015 using data on interest rates in the interbank market, the type of loans granted and the number of people that recored outstanding loans.

Keywords: Probability of default (PD), interest rate, credit risk, financial institutions, interest rate risk

JEL Classification: E00, G20, G21, G32

\section{To cite this article:}

Istrate, L.G., Ionescu, B.S. and Haralambie, M. (2016), Aspects of the impact of interest rate development on the probability of default, Audit Financiar, vol. XIV, no. 10(142)/2016, pp. 11491156, DOI: 10.20869/AUDITF/2016/142/1149

To link to this article:

http://dx.doi.org/10.20869/AUDITF/2016/142/1149 


\section{Introduction}

The policy of interest rate risk management lies in following closely with a relatively high frequency the present and projected financial impact that the implementation of the strategy or of the program in question.

The interest is the price of the capital used or the "rent" to be paid by the debtor for the right which is granted, that of using the borrowed capital. Generally, the interest rate level is correlated with the profit rate obtained by the entrepreneur. Quantification of the interest is achieved by using the interest rate, which is an instrument for influencing the demand and supply of credits.

A low interest rate leads to an increased demand for credits, resulting in favourable effects on production and economy, just as a high cost of credit generates lower demand.

This article attempts to capture the impact of interest rate on the probability of default upon maturity of loans. The analysis covers the period January 2013 December 2015 using data on interest rates in the interbank market, the type of loans (treasury, for equipment) and the number of people who registered outstanding loans.

\section{Literature review}

This paper aims to highlight the role that interest rate development has on the interbank market and the destination of the loans granted by credit institutions on the probability of default at maturity of loans, given the prudential rules for credit risk.

An important part of the research literature is devoted to macroecomice credit risk models following the methodology proposed by Wilson (1998). In his work "Portfolio Credit Risk", he proposes a new methodology for determining the distribution of loss resulting from related events of credit risk, in case of credit portfolios chosen arbitrarily for non-financial companies, both regionally and across the sector. An improvement to this approach is the creation of a link between the loss distribution, and the state of economy, as opposed to the approach based on historical averages, unconditioned by the macroeconomic framework, which does not accurately reflect the credit risk in the current economic conditions.
Chen, Cheng and Wu (2013) developed a class of dynamic models analysing the LIBOR rate and the SWAP rates by using three interest rate factors. They start from the idea that the impact of the interest rate on each industrial sector and the rating class are governed by one or two dynamic factors. He authors reached the conclusion that enterprises in different industries present a different dynamic regarding the credit risk but, in all the cases, the credit risk is influenced by the interest rate dynamics. More than that, the evolution of the interest rate doesn't offer only information regarding the credit risk for the current credits, but it also predicts the future dynamic of the credit risk.

In the same tim, Gambacorta and Mistrulli (2014) reached the conclusion that the interest rate of the short term credits is strongly correlated with the evolution of the three moths interest rate on the interbanking market. The authors noticed that the interest rate during the economic crisis was negatively correlated with the percentage of the credits granted by the banks to the corporate sector and the number of years between the first registration of a debtor in the Credit bureau is negatively correlated with the change of the crediting conditions. In the same time, certain characteristics of the banks affect the evolution of the interest rate. Thus, the banks which have less liquidities and are poorer capitalised were less willing to protect their corporate customers as to the increase of the interest rate.

Dell'Ariccia (2014) shows that the maintenance of a low interest rate can contribute to the growth of taking bank risks. When the banks adjust the capital's structure, the reduction of the interest rate generates a stronger gear effect and assuming a higher risk.

Landier, Sraer and Thesmar (2013) showed, using a sample made up of the trimester data of a sample of USA holdings during 1986-2013, that the banks present a significant exposure to the interest rate risk. In the same time, the authors reached the conclusion that it is difficult for a company confronted with a reduction of the credits to find quickly alternative financing sources. This leads to a decrease of the investments and of the jobs, as well as to financial difficulties.

Koh, Wei and Chwee (2015) concluded that the use of credit-scoring can help the credit institutions to determine the interest rate that they should ask from their customers and to determine the prices of the consumers' portfolios that present a risk of not being reimbursed higher because of a higher interest rate applied. 
According to Jimenez et al. (2014) whenever the monetary politics interest rates are smaller, the banks offer a bigger number of credits to the companies which present a higher risk.

Pesola (2001) proposed a dynamic panel approach for the study of banking crisis that affected the Nordic countries in the 1990s. The results of the study identify the indebtedness of borrowers as the most important explanatory variable that can approximate the level of financial fragility.

The integration of macroeconomic indicators in analyzing the credit risk was addressed, among others, by Castro (2013), who captured the link between macroeconomic indicators and credit risk, for a number of countries - Greece, Ireland, Portugal, Spain, and Italy (GIPSI), affected by the economic and financial crisis. Using a dynamic panel approach he notes that the credit risk is significantly affected by the macroeconomic environment: the credit risk increases when the gross domestic product (GDP) decreases, but the unemployment rate or interest rate increase, and are positively influenced by an appreciation of the real exchange rate .

Statistical techniques were used extensively in the construction of the classifying and credit-scoring model. Dănilă (2012) produced a scoring model to quantify the probability of default based on quantitative information and the determination of the power of predictivity of situations of default, given the determination of qualitative variables with regard to the impact on the repayment capacity of loan applicants.

Egami (2013) highlights a number of precautions measures to credit risk management using Levy processes and Sunet (2011) applied the multivaried exponential distribution Marshall-Olkin on credit risk. Meanwhile, Santoso et al. (2005) investigated bank failures in Japan and Indonesia using the logit model, while Canbas, Cabuk and Kilic (2005) proposed an integrated prediction system combining discriminant analysis, logit, probit and the analysis of main components.

\section{Research methodology}

The assessment of the default probability is the first step to determine and assess the credit risk. The major problems in the assessment of the default probability are generated by the limited available information.
To study the impact of interest rates on the number of debtors we have used the daily data of the reference rates ROBOR for a month ${ }^{1}$, as they appear on the website of the National Bank of Romania, as well as the monthly series representing the total amount of treasury loans, of the loans for equipment and the number of debtors with overdue payments to the credit institutions for the period January 2013 - December 2015.

The research aims to determine the connection between the evolution of the interest rate and the probability of default of the persons asking for credits, but also is the credit's destination (financing current activity/treasury of equipment purchase/investment) influences the decisions of the persons asking for credits regarding the payment of the contracted credits at the due date.

For an objective approach, we used:

- the dependent variable Number of distressed debt (DR) - Y, and

- the independent variables:

- Interest rate on the interbank market at one month (ROBOR1M) - $\mathrm{X}_{1}$

- Treasury loans $-\mathrm{X}_{2}$

- Loans for equipment - $X_{3}$;

as they appear on the internet page of the National Bank of Romania.

The research hypothesis is: The number of debtors with overdue credit payments depends on the evolution of the interest rate and the destination of the granted credits (treasury or equipment purchase).

In order to make the analysis we made empirical correlations between the dependent variable and the independent variables.

The variables subject to the analysis were worked so that they could generate a correlation matrix. It reflects the degree of influence of each independent variable on the default probability (Table 2).

In order to determine the correlation between the number of debtors with overdue payments and the dependent variables we analysed the data series with the EViews software package. We made the econometric analysis with logarithmic series, in orde to facilitate the interpretation of the results obtained.

1 For the analysis purpose, these were transformed in data series with month frequency 
We estimate that an increase of the reference interest rate value generates an increase of the default value, while the increase in the credits granted for the treasury's financing or for the equipment purchase is associated with a decrease of the default probability.

\section{Research results}

After finalizing the information's collection process for each variable analysed we obtained a database structured in Table 1.

\section{Table 1. Database with the values of the main variables}

\begin{tabular}{|c|c|c|c|c|}
\hline & ROBOR1M & $\begin{array}{l}\text { Owed amounts; } \\
\text { treasury credits }\end{array}$ & $\begin{array}{l}\text { Owed amounts; } \\
\text { equiments credits }\end{array}$ & $\begin{array}{c}\text { Number of debtors } \\
\text { with overdue } \\
\text { payments } \\
\text { (companies) }\end{array}$ \\
\hline & (\% p.a.) & (mil. RON) & (mil. RON) & (pers.) \\
\hline & $X_{1}$ & $X_{2}$ & $X_{3}$ & $Y$ \\
\hline December 2015 & 0.72 & 77,366 & 34,983 & 40,695 \\
\hline November 2015 & 0.87 & 77,228 & 35,140 & 43,189 \\
\hline October 2015 & 1.21 & 76,682 & 34,795 & 42,516 \\
\hline September 2015 & 1.41 & 76,267 & 33,982 & 42,842 \\
\hline August 2015 & 1.14 & 76,373 & 34,007 & 42,379 \\
\hline July 2015 & 1.01 & 75,404 & 33,824 & 41,604 \\
\hline June 2015 & 1.07 & 75,413 & 34,071 & 43,342 \\
\hline Mai 2015 & 1.27 & 74,090 & 33,792 & 43,615 \\
\hline April 2015 & 1.44 & 74,290 & 33,661 & 42,852 \\
\hline March 2015 & 0.91 & 68,013 & 30,348 & 42,890 \\
\hline February 2015 & 0.71 & 67,818 & 30,397 & 44,130 \\
\hline January2015 & 0.72 & 67,947 & 30,335 & 43,803 \\
\hline December 2014 & 0.85 & 67,679 & 30,837 & 44,197 \\
\hline November 2014 & 1.10 & 67,614 & 31,237 & 45,196 \\
\hline October 2014 & 2.54 & 67,575 & 31,239 & 44,599 \\
\hline September 2014 & 2.85 & 67,170 & 30,873 & 45,650 \\
\hline August 2014 & 1.96 & 66,726 & 31,023 & 46,145 \\
\hline July 2014 & 1.79 & 66,596 & 30,875 & 45,425 \\
\hline June 2014 & 2.00 & 66,572 & 30,490 & 47,468 \\
\hline May 2014 & 2.56 & 66,480 & 30,553 & 47,753 \\
\hline April 2014 & 2.62 & 66,162 & 30,184 & 47,922 \\
\hline March 2014 & 2.43 & 65,571 & 30,167 & 47,604 \\
\hline February 2014 & 3.48 & 65,636 & 30,268 & 48,392 \\
\hline January 2014 & 1.63 & 65,901 & 30,172 & 48,011 \\
\hline December 2013 & 2.00 & 65,749 & 30,163 & 47,781 \\
\hline November 2013 & 1.98 & 65,620 & 29,448 & 49,723 \\
\hline October 2013 & 2.95 & 66,089 & 29,909 & 48,911 \\
\hline September 2013 & 3.50 & 65,611 & 30,213 & 50,488 \\
\hline August 2013 & 3.81 & 66,036 & 30,247 & 48,632 \\
\hline July 2013 & 4.53 & 65,556 & 30,096 & 48,045 \\
\hline June 2013 & 4.41 & 66,288 & 30,297 & 49,761 \\
\hline Mai 2013 & 3.82 & 65,437 & 29,877 & 48,499 \\
\hline April 2013 & 4.40 & 64,995 & 29,881 & 48,773 \\
\hline March 2013 & 5.27 & 66,166 & 30,397 & 49,170 \\
\hline February 2013 & 5.84 & 65,791 & 30,220 & 49,715 \\
\hline January 2013 & 5.97 & 65,670 & 30,533 & 48,104 \\
\hline
\end{tabular}

Source: http://www.bnr.ro and authors' processing 
The correlation matrix of the variables analysed (Table 2) shows the fact that the high values of the interest rate are associated with high values of the default probability. This fact is emphasized by the positive value of the correlation between the default value and the evolution of the interest rate $(0.776457985)$.
In the same time, the negative values of the correlations between the default value and the treasury credits $(-0.839065268)$ or the credits for the equipment purchases $(-0.809370191)$ show that the high values of the indipendent variables are associated with small values of the default value. In the same time, the small values of the independent variables are associated with high values of the default probability.

Table 2. Correlation matrix of the analysed variables

\begin{tabular}{|l|r|r|r|r|} 
& $\begin{array}{c}\text { Number of debtors } \\
\text { with overdue } \\
\text { payments } \\
\text { (companies) }\end{array}$ & ROBOR1M & $\begin{array}{c}\text { Owed amounts; } \\
\text { treasury credits }\end{array}$ & $\begin{array}{c}\text { Owed } \\
\text { amounts; } \\
\text { equiments } \\
\text { credits }\end{array}$ \\
\hline $\begin{array}{l}\text { Number of debtors with overdue } \\
\text { payments (companies) }\end{array}$ & 1 & & & \\
\hline ROBOR1M & 0.776457985 & 1 & & 1 \\
\hline Owed amounts; treasury credits & -0.839065268 & -0.59165719 & & \\
\hline Owed amounts; equiments credits & -0.809370191 & -0.53445578 & 0.983583041 & \\
\hline
\end{tabular}

Source: authors' processing, 2016

In order to show the dependence between the selected variables in the chosen time frame we estimated the regression model in Excel (Table 3).

\begin{tabular}{|c|c|}
\hline \multicolumn{2}{|c|}{ SUMMARY OUTPUT } \\
\hline Multiple R & $\frac{s}{0008505008}$ \\
\hline R Square & 0.825381349 \\
\hline Adjusted R Square & 0.809010851 \\
\hline Standard Error & 1217.305525 \\
\hline Observations & 36 \\
\hline
\end{tabular}

Source: authors' processing, 2016

We can notice that the evolution of the number of debtors with overdue payments (companies) is influenced in proportion of $82.54 \%$ by the interest rate and the destination of the granted credits (R Square $=0.82538135)$.

Next, we made the analysis of the data series with EViews in order to determine the correlation between the number of debtors with overdue payments (companies) and the independent variables which were subject to analysis.

The check the hypothesis of the normality of the errors we used the Jarque-Berra test. This is based on the hypothesis that the normal distribution has an asymmetry coefficient equal with zero and a aplatisation coefficient equal with three. If the probability associated with the computed value of the test is low enough (the probability associated with the test doesn't exceed the table value), the hypothesis of errors' normality can be accepted.

The analysis of series histograms highlighted that these show characteristics of abnormal distribution having an Kurtotic excess (distribution is leptokurtotic), which reveals the existence of a great possibility to record extreme events (large variations in the interest rate or in the number of creditors that record overdue payments).

With the help of the linear regression we can determine the impact of the independent variables on the evolution of the number of debtors with overdue payments (companies).

The econometric results regarding the impact of interest rates and of the destinaton of loans granted on the probability of default at maturity of loans is as follows: 
Table 4. Research results in relation to independent variables

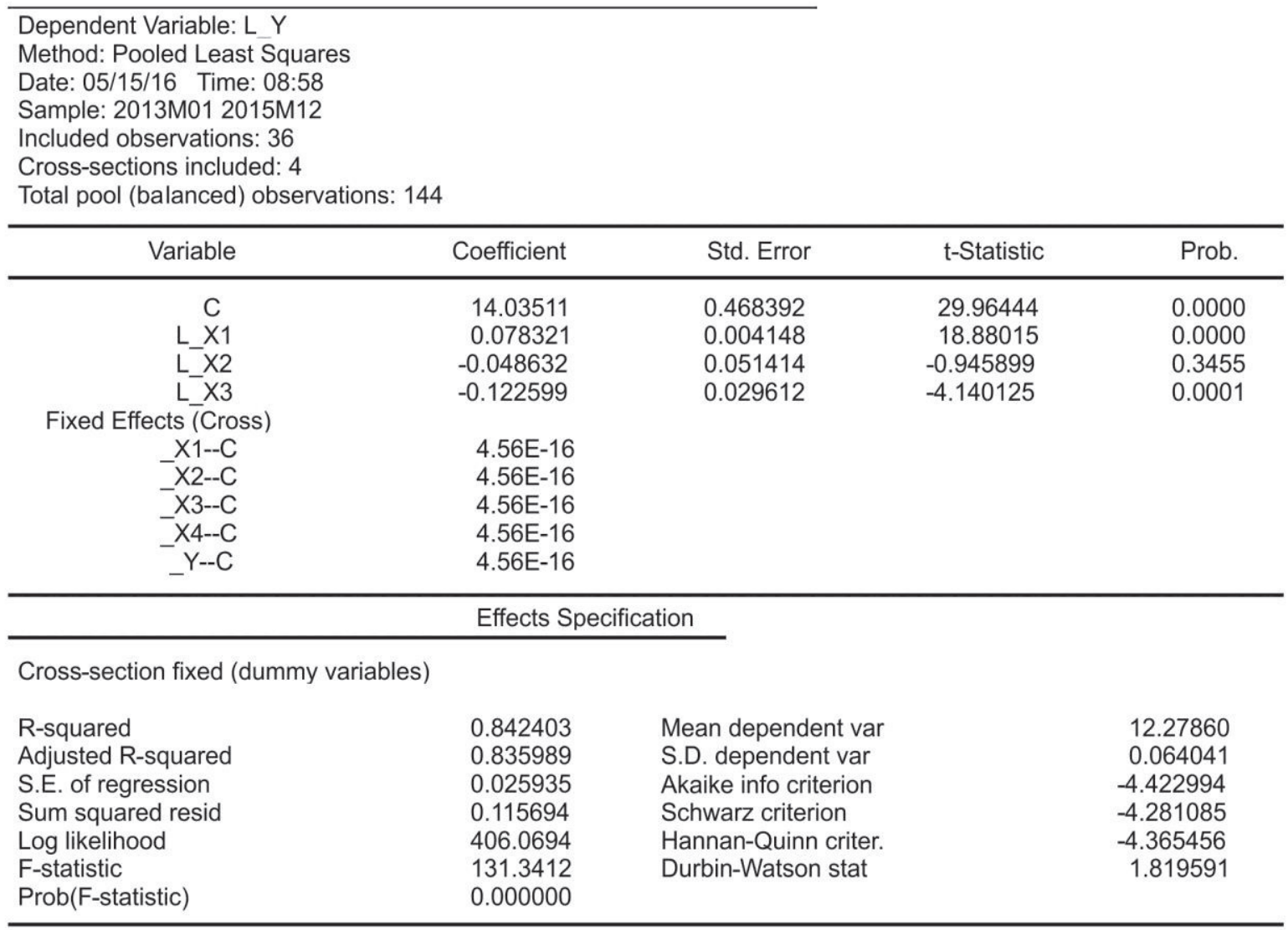

Source: authors' processing, 2016

As the probability associated with the test is lower than the most restrictive relevance level (1\%) for the variables $X_{1}$ (interest rate) and $X_{3}$ (credits for the equipments), but is above this level for the variable $X_{2}$ (treasury credits), the null hypothesis is rejected in the case of the variables $X_{1}$ and $X_{3}$ (the coefficients associated with these variables are significant from the statistical point of view) and is accepted in the case of the variable $X_{2}$ (the coefficient associated with this variable is not significant from the statistical point of view).

In the same time, the probability associated with the $F$ test shows that at least one of the regression coefficients is significant from the statistical point of view.
Considering that the dependent and the independent variables are expressed in naturals logarithms, the independent variables coefficients shows with what percentage is changing the dependent variable at a change with one percent of the independent variables. Thus, an increase of $1 \%$ of the value of the interest rate will determine an increase of $7.8321 \%$ of the number of bad debtors. In the same time, an increase of $1 \%$ of the treasury credits will determine a decrease of $4.8632 \%$ of the number of bad debtors. An increase of $1 \%$ of the credits for the equipment purchases will determine a decrease of $12.26 \%$ of the number of bad debtors. According to the econometric results the number of debtors to credit is influenced by the interest rate, 
meaning that an increase in interest rates on the interbank market determines an increase in the probability of default at maturity of loans contracted, while the destination of loans contracted (equipment, treasury) does not significantly influence PD.

\section{Ponclusions}

The financing by banks of certain activities in the field of industry, construction, agriculture, services or trade enables companies to increase the quality and volume of products and services provided. Also, a better orientation of these companies to the requirements of domestic and foreign markets takes place with beneficial effects on the reduction of macroeconomic imbalances inherent in an economy which is in full process of recovery of gaps as compared to the standards of developed countries.

The banks are confronted with the interest risk because of the exposure to unfavourable fluctuations of the interest rates on the market. As the interest bearing assets and liabilities become due, the market value of the assets and liabilities is influenced by the variance of the interest rate. The interest rate changes in different moments and in different percentages.
Under the circumstances of the economic crisis, banks have become more selective in providing financing to companies. Interbank liquidity maintainance below the high level recorded before the outbreak of the international economic crisis, and the financial difficulties registered by certain clients, will lead to a strategic reorientation of corporate lending, as follows:

- Financing mainly of investment projects along with a European partner (BERD, BEI) or by the government. This strategic shift will take place in the context of decrease of the indebtedness of the private sector and of the increase of the government indebtedness in the long term.

- Carefully analyzing the phases of the economic cycle and avoiding as far as manageable, the concentration of funding in sectors with a growth rate far too high at present and untenable in the long term.

- Focusing on the safety of investments made and diminishing the probability of materialization of credit risk by requiring additional securities or government securities.

\section{REFERENCES}

1. Canbas, S., Cabuk A. and Kilic S.B. (2005), Prediction of commercial bank failure via multivariate statistical analysis of financial structures: The Turkish case, European Journal of Operational Research, vol. 166, no. 2, pp. 528546, DOI: 10.1016/j.ejor.2004.03.023.

2. Castro, V. (2013), Macroeconomic determinants of the credit risk in the banking system: The case of the GIPSI, Economic Modelling, vol. 31, pp. 672683, DOI: 10.1016/j.econmod.2013.01.027.

3. Chen, R.-R., Cheng, X. and Wu, L. (2013), Dynamic interactions between interest-rate and credit risk: Theory and evidence on the credit default swap term structure, Review of Finance, vol. 17, no. 1, pp. 403-441, DOI: 10.1093/rof/rfr032.

4. Dănilă, O.M. (2012), Evaluarea riscului de credit din perspectiva Acordului Basel, Economie teoretică şi aplicată, vol. XIX, no. 3, pp. 60-75.
5. Dell'Ariccia, G., Laeven, L. and Marquez, R. (2014), Real interest rates, leverage, and bank risk-taking, Journal of Economic Theory, vol. 149, pp. 65-99, DOI: 10.1016/j.jet.2013.06.002.

6. Egami, M. and Yamazaki, K. (2013), Precautionary measures for credit risk management in jump models, Stochastics An International Journal of Probability and Stochastic Processes: formerly Stochastics and Stochastics Reports, vol. 85, no. 1 , pp.111-143, DOI: 10.1080/17442508.2011.653566.

7. Eviews (1995), User Guide, Version 2.0, QMS Quantitative Micro Software, Irvine, California, p.140-141.

8. Gambacorta, L. and Mistrulli, P.E. (2014), Bank heterogeneity and interest rate setting: what lessons have we learned since Lehman Brothers?, Journal of Money, Credit and Banking, vol. 46, no. 4, pp.753-778, DOI: 10.1111/jmcb.12124. 
9. Koh, H.C., Wei, C.T. and Chwee, P.G. (2006), A twostep method to construct credit scoring models with data mining techniques, International Journal of Business and Information, vol. 1, no. 1, pp. 96-118.

10. Jiménez, G. (2014), Hazardous Times for Monetary Policy: What Do Twenty Three Million Bank Loans Say About the Effects of Monetary Policy on Credit Risk Taking?, Econometrica, vol. 82, no. 2, pp. 463-505, DOI: 10.3982/ecta10104.

11. Landier, A., Sraer, D. and Thesmar, D. (2013), Banks' exposure to interest rate risk and the transmission of monetary policy, no. w18857, National Bureau of Economic Research, DOl: 10.3386/w18857.

12. Pesola, J. (2001), The Role of Macroeconomic Shocks in Banking Crisis, Bank of Finland,
Discussion Paper 6, SSRN Electronic Journal, DOI: 10.2139/ssrn.317945.

13. Santoso, W., Montgomery, H., Besar, D. and Hanh, T. (2005), Coordinated failure? a cross-country bank failure prediction model, Asian Development Bank Institute, Discussion Paper nr. 32.

14. Sunet, Y., Mendoza-Arriaga, R. and Linetsky, V. (2011), Marshall-Olkin Multivariate Exponential Distributions, Multidimensional L'evy Subordinators, Efficient Simulation, and Applications to Credit Risk, SSRN Electronic Journal, September 2011.

15. Wilson, T.C. (1998), Portfolio Credit Risk - Federal Reserve Bank of New York, Economic Policy Review, no. 3, pp. 71-82. 